Original Research Paper

\title{
Measuring Intra-City Eco-Efficiency Variations of Urban Infrastructures in Jeddah
}

\author{
Mohammed Aljoufie and Alok Tiwari \\ Department of Urban and Regional Planning, King Abdulaziz University, Saudi Arabia
}

\author{
Article history \\ Received: 11-04-2015 \\ Revised: 11-12-2015 \\ Accepted: 12-05-2016 \\ Corresponding Author: \\ Mohammed Aljoufie \\ Department of Urban and \\ Regional Planning, King \\ Abdulaziz University, Saudi \\ Arabia \\ Email:maljufie@kau.edu.sa; \\ aljoufie@itc.nl
}

\begin{abstract}
Saudi cities are experiencing construction booms linked to urban infrastructure services and the Kingdom's second largest city, Jeddah, is not an exception. As these booms are associated with urban expansion and rapid population growth, the major challenge confronting urban planners is the ensuring of resource efficiency given the offered infrastructure. In fact, reducing the consumption of resources and the impact of consumption on the environment is a serious concern with respect to the improved value of sustainable urban development as well as society. This paper attempts to measure intracity spatial eco-efficiency variations of the major urban infrastructures of Jeddah. These infrastructures include water supply, public transportation, social businesses, energy consumption, solid waste generation and green areas, all of which are assumed to be offered as a skeleton for upcoming urban environmental plans that will then lead to the reconfiguring, retrofitting or replacing of infrastructures in the city, thus driving it towards a green economy.
\end{abstract}

Keywords: Urban Infrastructure, Eco-Efficiency, Retrofitting, Green Economy

\section{Introduction}

Measuring or assessing (Kuosmanen, 2005) is the secret to established management practices. Measuring the sustainability of cities contributes to overall good city management as sustainability indicators and composite indices are recognised as effective tools for policy making (Singh et al., 2009).

Assessing eco-efficiency inspires urban planners and decision makers to search for the least costly and most environmentally friendly alternatives available (Ribarova et al., 2013). While urban environments drive economic development, their avid hunger for growth combined with their size, results in an alarming increase in resource consumption in dense areas of cities (Schaffer and Vollmer, 2010).

In fact, sustainability does not prevent resource consumption, but rather, it aims to efficiently consume resources. While material and resource flows are inherent to and incurred by the cities' infrastructure, eco-efficiency is the indicator to promote transformation towards sustainability. However, there is a considerable lack of research regarding the development of this indicator. In particular, there is a considerable absence in the literature on the development of such an indicator to analyse intracity eco-efficiency variations in urban infrastructures.

Sustainability of Urban infrastructure is crucial for urban environment (Choguill, 1996) because they regulate flow of natural and artificial resources consumed in the urban areas. The eco-efficiency of urban infrastructure has significant importance with respect to rapidly urbanising and globalising cities such as Jeddah, where urban infrastructure development choices made today determine the success of cities to deliver services to its stakeholders while growing competitively within a protected environment for decades to come (UNESCAP, 2011).

Hence, this paper attempts to develop a measure for intra-city spatial eco-efficiency of selected urban infrastructure amenities in Jeddah such that the amenities can be strategically planned to offer sustainable reconfiguring and retrofitting.

\section{Eco-Efficiency of Urban Infrastructure: Theoretical Background}

Brunt land Commission suggested sustainable development as a development paradigm that aims to 
meet the needs of the present generation without compromising the capabilities of future generations (WCED, 1987). Saudi cities have recently begun focusing on sustainability because of the increasing awareness that economic growth usually comes at the cost of environmental impact, such as the consumption of the earth's resources has surpassed the earth's available resources. In 2012, the UAE launched 'The Arab Green Economy Initiative", which guides their economy from a virtual to a real sustainability perspective (UNDP, 2012). The environmental and climate changes impact related burdens as the production and consumption of resources call for a more efficient use of environmental resources. The concept of eco-efficiency was initially developed as a business link to sustainability (Schaltegger and Sturm, 1990; Freeman et al., 1973). It was later adopted by the WBCSD (2000) with the slogan, 'doing more with less' or 'creating more value with less impact'. Eco-efficiency suggests a substantial change from non-sustainability to sustainability (Mickwitz et al., 2006). Eco-efficiency offers solutions such as optimising resource values by reducing the use of resources and thereby reducing the environmental impact Eco-efficiency promotes the development of a cyclic economy that is resource conservative in nature rather than a traditional linear economy that consumes resources and produces waste
(Byström, 2012). A paradigm shift from conventional environmental reporting to sustainability reporting or ecoefficiency reporting, which comprises the Triple Bottom Line (TBL)-social, economic and environmental aspectshas been evidenced in the last few years (Fet, 2003). Ecoefficiency reporting advises cities' economies to reconfigure their infrastructure towards a low-carbon transition plan (Bulkeley et al., 2014).

\section{Methodology}

\section{Study Area}

Jeddah is the second largest city in the Kingdom of Saudi Arabia with a population of 3.4 million in 2014. The population is expected to grow to over 5 million by 2029 (JM, 2009), when the city will then rank 5th, based on size, among all Arabian cities (UN-HABITAT, 2012a). Jeddah is located on the west coast of the Kingdom in the middle of the eastern shore of the Red Sea and it is surrounded by the plains of the Tahoma to the east (Fig. 1). Being a coastal city, its location is more environmentally sensitive to the kingdom. Furthermore, the city is experiencing a transition as many mega infrastructural amenities designed to provide the city's residents a better quality of life are either provisioned for or planned.

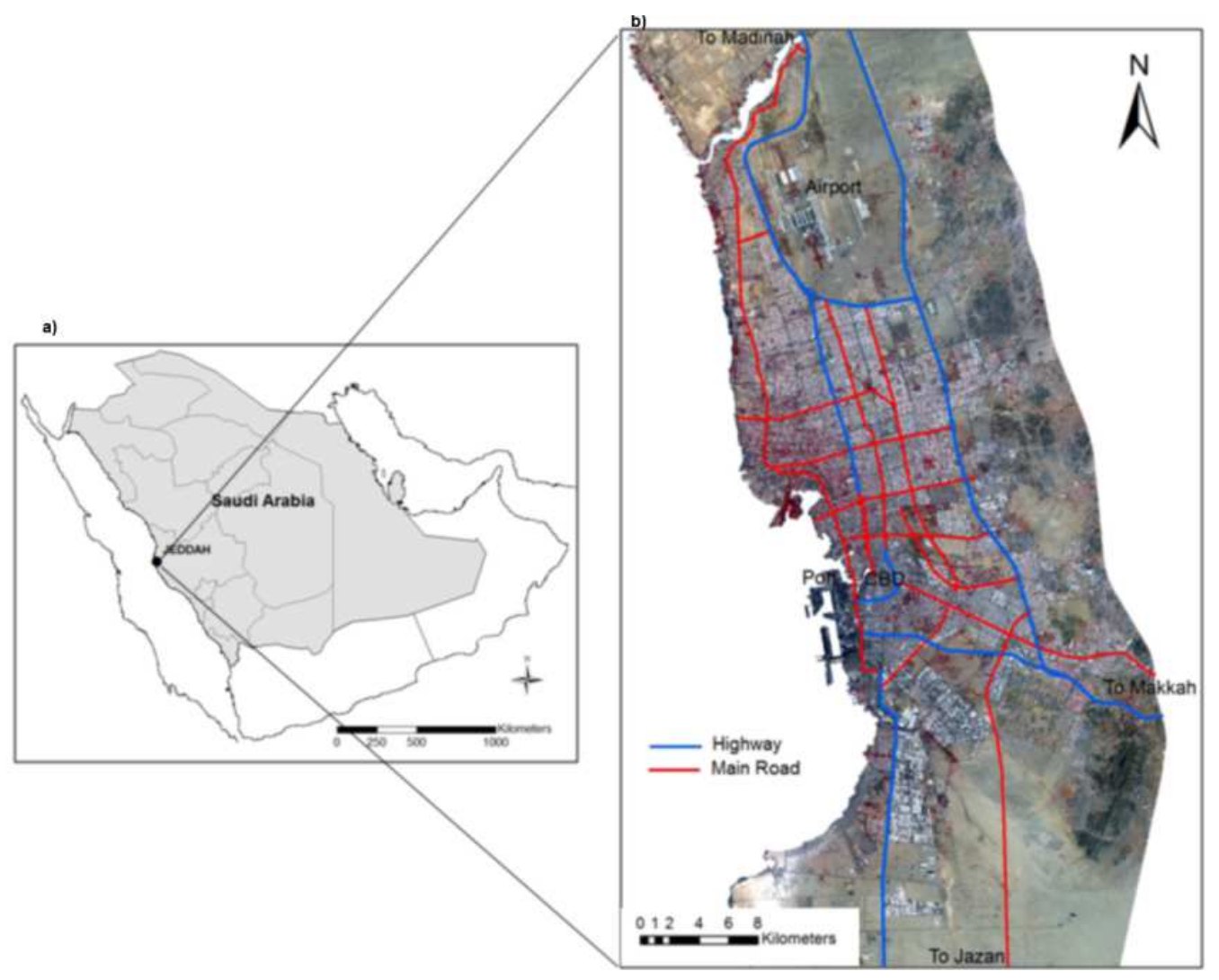

Fig. 1. (a) Geographic location of Jeddah (b) Jeddah city 
Jeddah's history, location and unique role in relation to Hajj have contributed to shaping its urban form and demographic profile. Attracting migrant workers and pilgrims from the entire Islamic world, the city is perceived as a place of opportunity. The rapid growth in population (natural and migratory) in the last four decades has coincided with the Kingdom's enormous increase in wealth, which, in turn, has resulted in Jeddah's unprecedented rate of physical expansion. The urban area of Jeddah has exceeded the current capacity of its infrastructure, thus leading to structural problems with respect to city's ability to provide adequate water, sewage and roadways. This growth has also left the city with a number of structural challenges, including numerous areas of vacant land as well as a dependency on private cars for transportation.

\section{Data Collection and Preparation}

In this study, six key urban infrastructure resources have been chosen in varying units to determine environmental cost, namely, water, energy, solid waste, green cover, public transport and social business areas (mall in the case of Jeddah). These constitute major urban infrastructure, all of which are pertinent for environmental betterment and improved quality of life in a city.

The analysis was conducted at the district level because of the homogenous character of districts in Jeddah. A simple random sampling technique was applied to obtain household level water, energy and solid waste related data at the district level. The remaining infrastructure data, including green infrastructure, public transport route length and social business areas, were first extracted from satellite imageries in conjunction with secondary data A GIS-based approach was then used to disaggregate the extracted data regarding green infrastructure, public transport route length and social business areas at the district level.

\section{Eco-Efficiency Indicators}

Though numerous indicators have been recommended by scholars and agencies to measure sustainability and eco-efficiencies (Singh et al., 2009) the UN (2009) adheres to the following equation:

$$
\text { Eco }- \text { efficiency }=\frac{\text { Environmental Cost }}{\text { Economic Output }}
$$

As previously indicated herein, environmental cost may refer to pollution emissions, resources used or costs associated with environmental burden, while economic output can be expressed in value added through benefits, units of product or service or costs associated with environmental burden. In this study, environmental cost refers to urban infrastructure resources used, while the economic output refers to the service area expressed as per hectare $(10,000$ square meters $)$ of land parcel.

Hence:

Eco - efficiency $=\frac{\text { Infrastrcture resource uses }}{\text { Service area }}$

After computing the eco-efficiency of each infrastructure resource at the district level, the resources were categorised on the basis of natural breaks (jenks) and a weight was assigned to each infrastructure resource ranging from very low (0) to very high (5).

Accordingly, to calculate the eco-efficiency for public transport (EEtr):

EEtr $=\frac{\text { Length of publictransport routes in meters }}{\text { Geographical area of district in hectares }}$

Allocated weights for public transport ecoefficiencies (EEtr) are depicted in Table 1.

To calculate the eco-efficiency for water supply (EEwt):

$$
\text { EEwt }=\frac{\text { Watersupply in killoleters }}{\text { Geographical area of district in hecatres }}
$$

Allocated weights for water supply eco-efficiencies (EEwt) are presented in Table 2.

To calculate the eco-efficiency for energy (electricity):

EEen $=\frac{\text { Electricity consumtion in killowatt Hours }}{\text { Geographical area of district in hecatres }}$

Allocated weights for energy eco-efficiencies (EEen) are presented in Table 3 .

To calculate the eco-efficiency for solid waste generation (EEsw):

$E E s w=\frac{\text { Daily solid waste generation in quintals }}{\text { Geographical area of district in hecatres }}$

Allocated weights for solid waste generation ecoefficiencies (EEsw) are presented in Table 4.

To calculate the eco-efficiencies for green infrastructure (EEgi):

$E E g i=\frac{\text { Green area in square meters }}{\text { Geographical area of district in hecatres }}$

Allocated weights for green infrastructure ecoefficiencies are presented in Table 5 (EEgi). 
Mohammed Aljoufie and Alok Tiwari / American Journal of Environmental Sciences 2016, 12 (3): 152.168 DOI: 10.3844/ajessp.2016.152.168

Table 1. Assigned Weights for Public Transport Eco-efficiencies (EEtr)

\begin{tabular}{lll}
\hline Weighted score & Category & $\begin{array}{l}\text { Length of public transport routes } \\
\text { (in meters) per hectare of land }\end{array}$ \\
\hline 1 & Very low & 0.0 to 2.8 \\
2 & Low & 2.8 to 10.0 \\
3 & Moderate & 10.0 to 19.0 \\
4 & High & 19.0 to 35.0 \\
5 & Very high & 35.0 to 57.0 \\
\hline
\end{tabular}

Table 2. Assigned Weights for Water Supply Eco-efficiencies (EEwt)

\begin{tabular}{lll}
\hline Weighted score & Category & $\begin{array}{l}\text { Water Supply (in kilolitres) } \\
\text { per hectare of land }\end{array}$ \\
\hline 1 & Very low & 75.4 to 103.8 \\
2 & Low & 45.2 to 75.4 \\
3 & Moderate & 14.9 to 45.2 \\
4 & High & 6.1 to 14.9 \\
5 & Very high & 0.5 to 6.1 \\
\hline
\end{tabular}

Table 3. Assigned Weights for Energy Eco-efficiencies (EEen)

\begin{tabular}{lll}
\hline Weighted score & Category & $\begin{array}{l}\text { Electricity supply (in kilowatt } \\
\text { hours) per hectare of land }\end{array}$ \\
\hline 1 & Very low & 329.0 to 454.0 \\
2 & Low & 197.0 to 329.0 \\
3 & Moderate & 65.3 to 197.0 \\
4 & High & 22.7 to 65.3 \\
5 & Very high & 0.0 to 22.7 \\
\hline
\end{tabular}

Table 4. Assigned Weights for Solid Waste Generation Eco-efficiencies (EEsw)

\begin{tabular}{lll}
\hline Weighted score & Category & $\begin{array}{l}\text { Amount of solid wastes generated daily } \\
\text { (in quintals) per hectare of land }\end{array}$ \\
\hline 1 & Very low & 47.0 to 65.0 \\
2 & Low & 28.0 to 47.0 \\
3 & Moderate & 13.0 to 28.0 \\
4 & High & 3.8 to 13.0 \\
5 & Very high & 0.0 to 3.8 \\
\hline
\end{tabular}

Table 5. Assigned Weights for Green Infrastructure Eco-efficiencies (EEgi)

\begin{tabular}{lll}
\hline Weighted score & Category & \multicolumn{2}{c}{$\begin{array}{c}\text { Green area (in square meters) } \\
\text { per hectare of land }\end{array}$} & 0.0 to 71.2 \\
\hline 1 & Very low & 71.2 to 175.4 \\
2 & Low & 175.4 to 336.8 \\
3 & Moderate & 336.8 to 663.9 \\
4 & High & 663.9 to 1141.0 \\
5 & Very high & \\
\hline
\end{tabular}

Table 6. Assigned Weights for Social Businesses Eco-efficiencies (EEsb)

\begin{tabular}{lll}
\hline Weighted score & Category & $\begin{array}{c}\text { Area of malls (in square } \\
\text { meters) per hectare of land }\end{array}$ \\
\hline 1 & Very low & 0.0 to 130.0 \\
2 & Low & 130.0 to 210.0 \\
3 & Moderate & 210.0 to 303.0 \\
4 & High & 303.0 to 559.0 \\
5 & Very high & 559.0 to 1265.0 \\
\hline
\end{tabular}

To calculate the eco-efficiency for social businesses (EEsb):

EEs $b=\frac{\text { Area of malls in square meters }}{\text { Geographical area of sistrict in hecatres }}$

Allocated weights for social businesses ecoefficiencies (EEsb) are presented in Table 6.
Table 7. Classified City-level Eco-efficiency Index

\begin{tabular}{ll}
\hline EEI & Eco-efficiency \\
\hline 1 & Very low \\
2 & Low \\
3 & Moderate \\
4 & High \\
5 & Very high \\
\hline
\end{tabular}


After determining the infrastructure resource ecoefficiencies, a composite index was developed at the district level. The index depicts the overall spatial sustainability performance of a district. Then, after calculating the sustainability performance, the following formula is applied:

$E E I i=\frac{\Sigma\left(\begin{array}{l}E E t r i+E E w t i+E E g i i \\ +E E e n i+E E s w i+E E s b i\end{array}\right)}{C u i}$

where, EEIi is the eco-efficiency index for the ' $i$ 'th district; EEtri, EEwti, EEgii, EEeni, EEswi and EEsbi are the weighted eco-efficiencies for the ' $i$ 'th district for public transport, water supply, green infrastructure, energy, solid wastes and social businesses, respectively; and Cui denotes the number of classes of the urban infrastructures.

Additionally, a city-level eco-efficiency index was created and classified to denote district level variations of eco-efficiencies for Jeddah as depicted in Table 7.

It is statistically noteworthy, as evidenced in Table 7, that the highest possible eco-efficiency in a district 5 ' 5 ', while the lowest is ' 1 '.

\section{Results}

Sustainable infrastructure ensures the prosperity of a city (UN-HABITAT, 2012b), while huge environmental resource consumption and limited availability of green and open spaces hampers carrying capacities in urban areas (Mitlin and Satterthwaite, 1996). Accordingly, measuring eco-efficiency becomes more important for the sustainable planning of a city's environment. The findings of this study with respect to eco-efficiency of a city are as follows.

\section{Eco-Efficiency of Public Transport}

The importance of an efficient public transport system is not debatable and the need to develop such a system is crucial for decreasing the carbon footprint of a city. However, such development is lacking in Jeddah, as Aljoufie et al. (2013) have indicated the dominance of the car as a means of transportation and a decline in the emphasis placed on public transportation. The share of daily car trips in Jeddah was $96 \%$ in 2012. Conversely, public transportation, walking and cycling jointly represented only $4 \%$ of the total trips in the city (AECOM, 2012). At present, adequate public transport is available in only a few districts. Figure 2 shows the district level eco-efficiency of public transportation infrastructure in Jeddah. Of the 70 reporting districts in Jeddah, 25 do not have a single meter of public transportation routes, while only three districts-Al Sabeel, Al Balad and Al Sahefah have transportation routes of more than 35 kilometres per hectare, which is considered very high with respect to eco-efficiency. The districts that demonstrate high eco-efficiency are located in the city centre. District level eco-efficiency of public transport infrastructure is presented in Table 8.

The factors that likely obstruct the sustainable development of public transportation in Jeddah include poor service offered by the current public transportation system, cheap fuel prices, cheap automobiles and low social acceptability. Nonmotorised transport modes, such as walking and cycling, are also not well received in the city because of the adverse climate conditions and the absence of adequate supporting road features (secured pedestrian sidewalks and bicycle tracks).

\section{Eco-efficiency of Water Supply}

Water is both an economic and an ecological resource (Huang et al., 2013) and in urban areas, the demand for this resource ensues due to the use of alternative hydro-systems (Grimm et al., 2008). Figure 3 and Table 9 show the district level ecoefficiency of water supply in Jeddah. It is noted that eco-efficiency of water supply is high and very high, cumulatively, in approximately $55.7 \%$ of the districts located in the urban peripheries where there are new districts and low population density. On the other hand, the eco-efficiency of three districts concentrated in Jeddah's city centre was very low.

Urbanisation consistently increases water-related environmental vulnerabilities, which include water pollution, urban floods, the depletion in the quantity and quality of groundwater, etc. Jeddah's groundwater is highly polluted because of high concentrations of nitrates resulting in the water being declared unusable. The daily water consumption of Jeddah is 1 million cubic meters, $85 \%$ of which is supplied through a piped distribution system while the remaining $15 \%$ is supplied via water tankers. The analysis further reveals that per capita water consumption averages 190 litters per day and ranges from 90 litters in the lowest use cases to 275 litters in the highest use cases. Unaccounted for water due to leakage and other factors is $30 \%$, which is equal to 191 thousand cubic meters per day (Al-Sefry and Sen, 2006), a factor that negatively affects the eco-efficiency of the water supply. It is further noteworthy that the entire water supply of the city is cycled through hydrocarbon fuelled desalination plants. This means that the consumption of water in the city is, in essence, the indirect consumption of fossil fuel. Undoubtedly, continuing to supply water in this manner will 
increase the negative environmental impacts and impede the greening of the city's economy. Ecoefficiency of Water infrastructure is also crucial because of its multiplier effects which can be either of positive or negative, for instance if water is consumed in an inefficient way it could lead problems for wastewater infrastructure hampering city's sustainability (Beck and Cummings, 1996) more adversely.

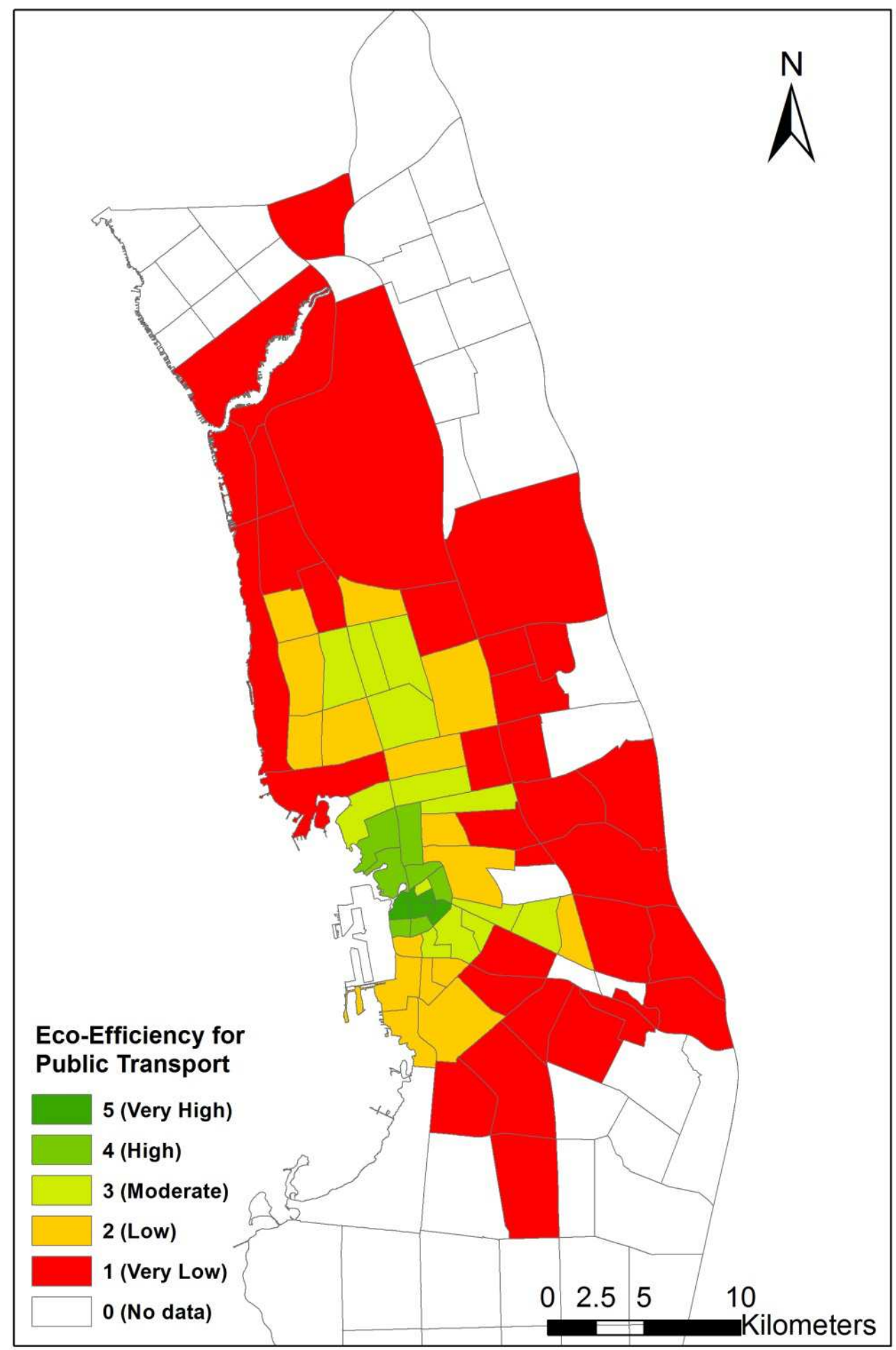

Fig. 2. Eco-efficiency for public transport 


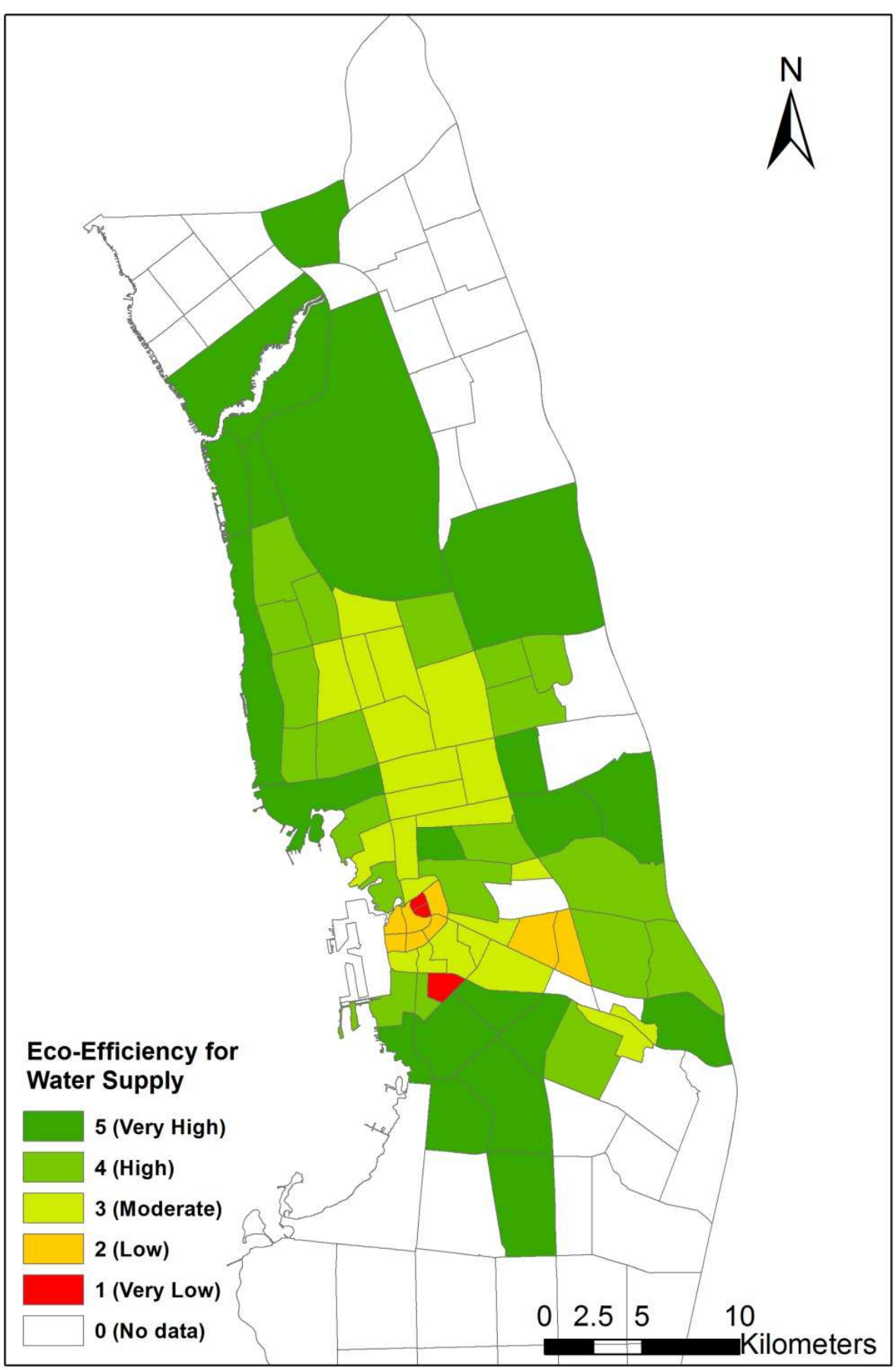

Fig. 3. Eco-efficiency for water supply

Table 8. District level eco-efficiency of public transportation routes in Jeddah

\begin{tabular}{lcr}
\hline EE $_{\text {tr }}$ & No. of districts & $\%$ \\
\hline Very low & 34 & 48.6 \\
Low & 14 & 20.0 \\
Moderate & 13 & 18.6 \\
High & 6 & 8.5 \\
Very high & 3 & 4.3 \\
Total & 70 & 100.0 \\
\hline
\end{tabular}

Table 9.District level eco-efficiency of water supply in Jeddah

\begin{tabular}{lcr}
\hline EE $_{\mathrm{wt}}$ & No. of districts & $\%$ \\
\hline Very low & 3 & 4.3 \\
Low & 6 & 8.6 \\
Moderate & 22 & 31.4 \\
High & 19 & 27.1 \\
Very high & 20 & 28.6 \\
Total & 70 & 100.0 \\
\hline
\end{tabular}




\section{Eco-Efficiency of Green Infrastructure}

Kambites and Owen (2006) defined green infrastructure as the connected networks of multifunctional, predominately unbuilt space that supports both ecological and social activities and processes. As such, green infrastructure is multifunctional as it can solve many urban problems almost simultaneously. For example, it can absorb carbon emissions from automobiles, contribute to environmental improvements, enhance urban health, sustain place making and leisure activities, decrease the urban heat island effect, increase social cohesion and interactions, etc. Because of the many potential benefits, urban professionals' concern regarding green infrastructure has increased in recent years (Krellenberg et al., 2014, Schäffler and Swilling, 2013, Alberti et al., 2003).

Figure 4 and Table 10 depict the district level ecoefficiency of green infrastructure in Jeddah. It is evidenced that very low and low eco-efficiencies are dominant in Jeddah, while high and very high ecoefficiencies comprise collectively a low percentage. Thus, there is a significant need for green infrastructure in most of the districts of Jeddah Unfortunately, however, green infrastructure in Jeddah faces many challenges, two of which are the arid climate and the lack of water, both of which deter the development of green infrastructure in the city.

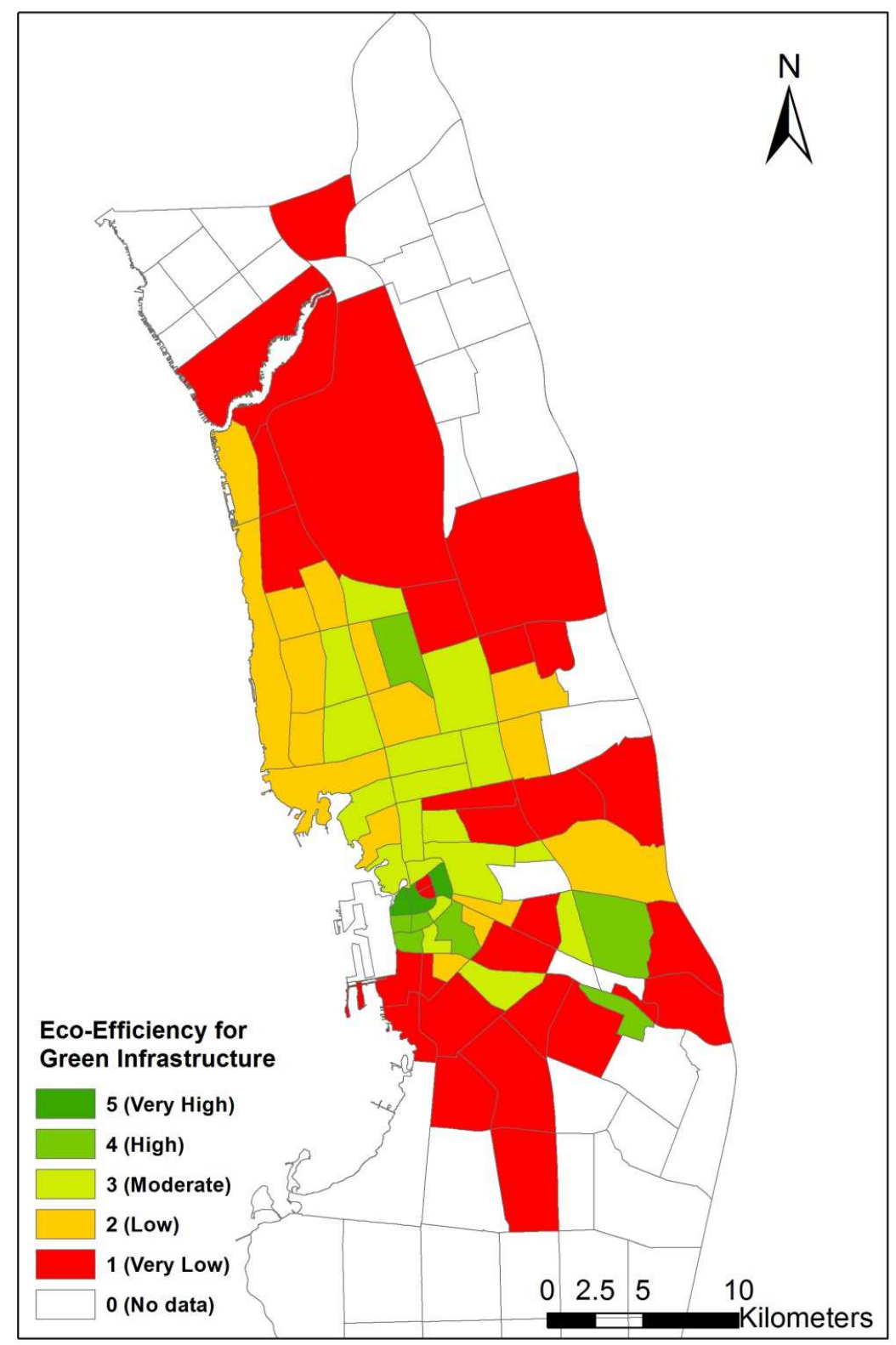

Fig. 4. Eco-efficiency for green infrastructure 


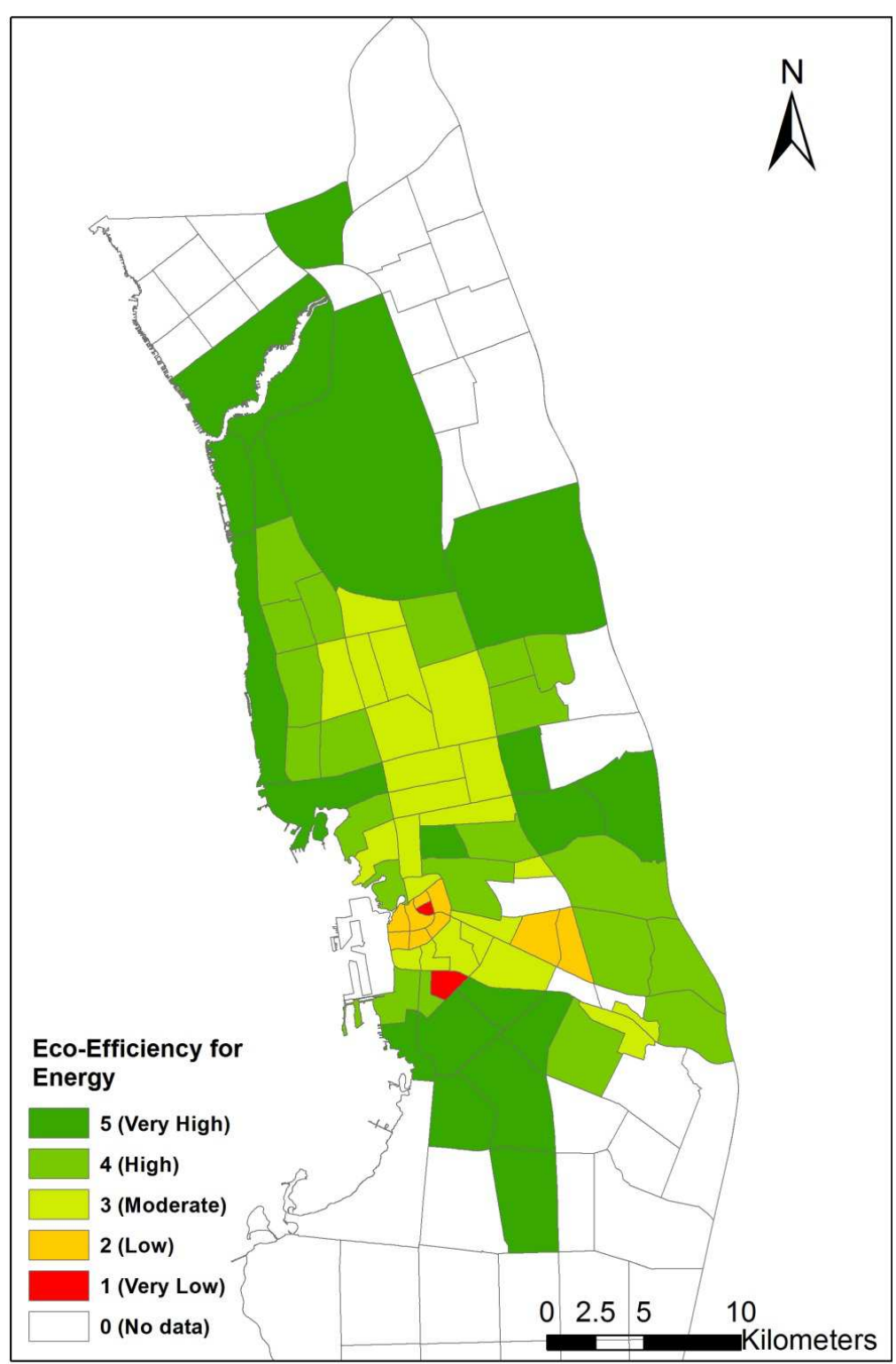

Fig. 5. Eco-efficiency for energy

Table 10. District level eco-efficiency of Green Infrastructure in Jeddah

\begin{tabular}{lcr}
\hline EE $_{\mathrm{gi}}$ & No. of districts & $\%$ \\
\hline Very low & 28 & 40.0 \\
Low & 16 & 22.9 \\
Moderate & 18 & 25.7 \\
High & 6 & 8.6 \\
Very high & 2 & 2.8 \\
Total & 70 & 100.0 \\
\hline
\end{tabular}

\section{Eco-Efficiency of Energy Infrastructure}

Similar to water supply, electricity supply in Jeddah depends on hydrocarbon based fuels. As most of the electricity is used for air-conditioning, the production and consumption of electricity in the city generates higher carbon emissions, which translate into a larger ecological footprint. With respect to Beijing, Zhang et al. (2013) proposed the expansion of green spaces as a tool for energy savings and emissions reduction.

Table 11 and Fig. 5 indicate high consumption of electric energy in 20 districts, thus leading to an extremely low eco-efficiency, while eco-efficiency is comparatively very high in 19 districts of the city. It is noted that low, very low and moderate ecoefficiencies are concentrated in the city centre of Jeddah and in the highly dense areas of the city. The rationalisation of energy consumption in conjunction with climate conditions are the main challenges facing energy infrastructure not only in Jeddah but in all Saudi cities. 


\section{Eco-Efficiency of Solid Wastes}

Massive amounts of municipal solid waste and its improper handling and management negatively impacts human and environmental health as well as sanitation in many of the world's cities (Da Silva et al., 2005; Diaz et al., 2005; Rotich et al., 2006; Rouse, 2006). Urbanisation, rapid population growth and unsustainable resource use patterns in cities has worsened the problems associated with the proper handling of the solid wastes generated by cities
(Suocheng et al., 2001). The average amount of daily per capita generated solid waste in Jeddah is 1.2 kilograms, though its spatial generation varies.

Figure 6 and Table 12 depict the district level ecoefficiency of solid waste generation in Jeddah. The ecoefficiency of solid wastes was found to be very low in two districts of Jeddah where generated waste equalled more than 47 quintals per hectare of land, while it was below 3.8 quintals per hectare of land in 20 districts. Recycling and solid waste management are the main challenges facing solid waste generation in Jeddah.

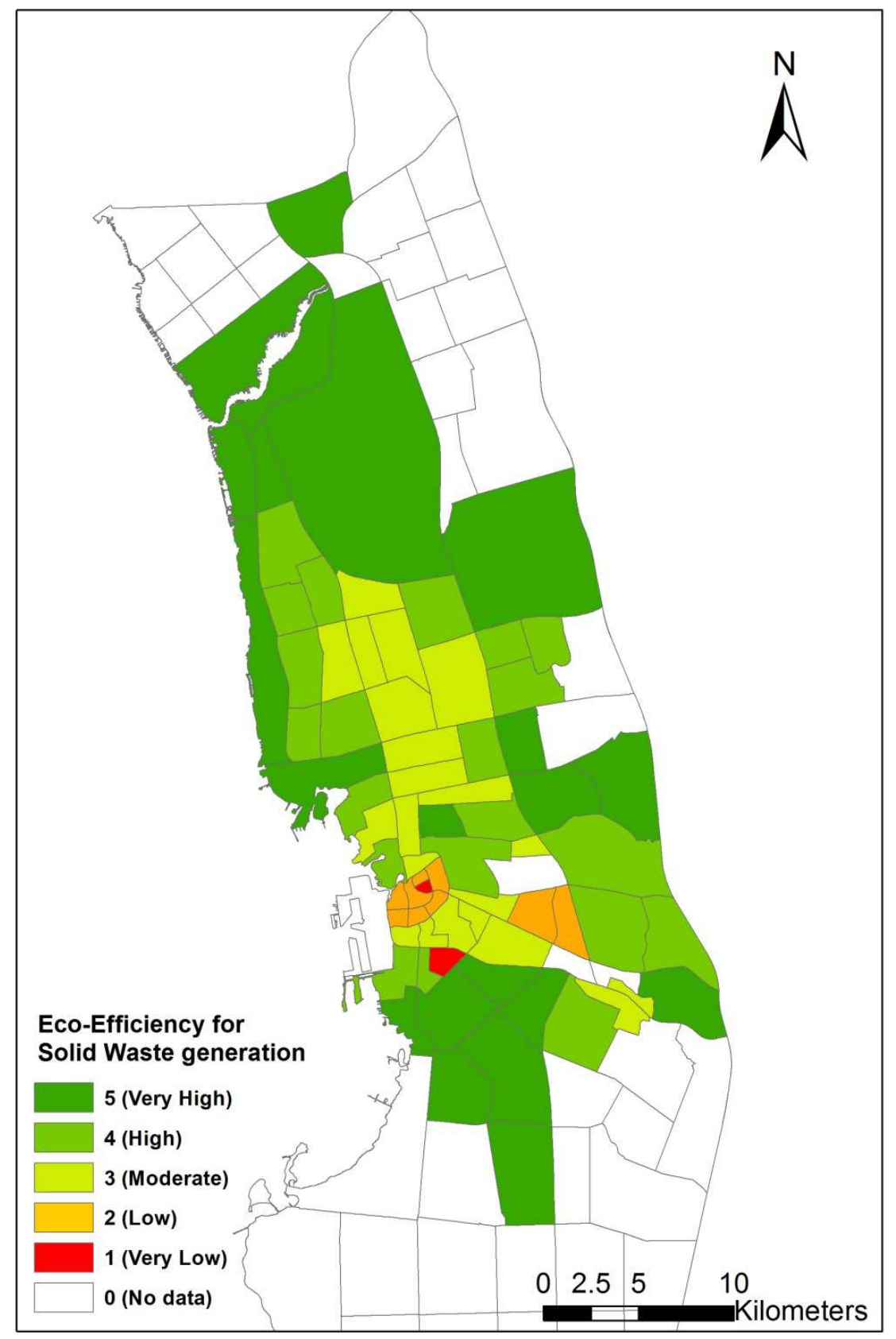

Fig. 6. Eco-efficiency for solid waste generation 
Table 11. District level eco-efficiency of Energy Infrastructure in Jeddah

\begin{tabular}{lcr}
\hline EE $_{\text {en }}$ & No. of districts & $\%$ \\
\hline Very low & 2 & 2.9 \\
Low & 7 & 10.0 \\
Moderate & 22 & 31.4 \\
High & 20 & 28.6 \\
Very high & 19 & 27.1 \\
Total & 70 & 100.0 \\
\hline
\end{tabular}

\section{Eco-Efficiency of Social Business}

Malls are now inseparable features of any city environment. As such, they offer a social space especially for the families and children within the city's boundaries.
Hence, their efficiency or sufficiency is worth measuring. Richard et al. (1989) concluded that malls are the most preferred place for social interaction and shopping and accordingly, these social business areas offer improved quality of life and prosperity to city residents.

Figure 7 and Table 13 depict the district level ecoefficiency of social businesses in Jeddah. The social businesses in approximately $85 \%$ of Jeddah's districts demonstrate low eco-efficiency, whereas three districts receive an eco-efficiency rating of very high. There is an unequal distribution as well as a dispersed pattern of moderate to very high eco-efficiency with respect to social businesses in Jeddah, which is escalated by the absence of a strict urban centre hierarchy in Jeddah.

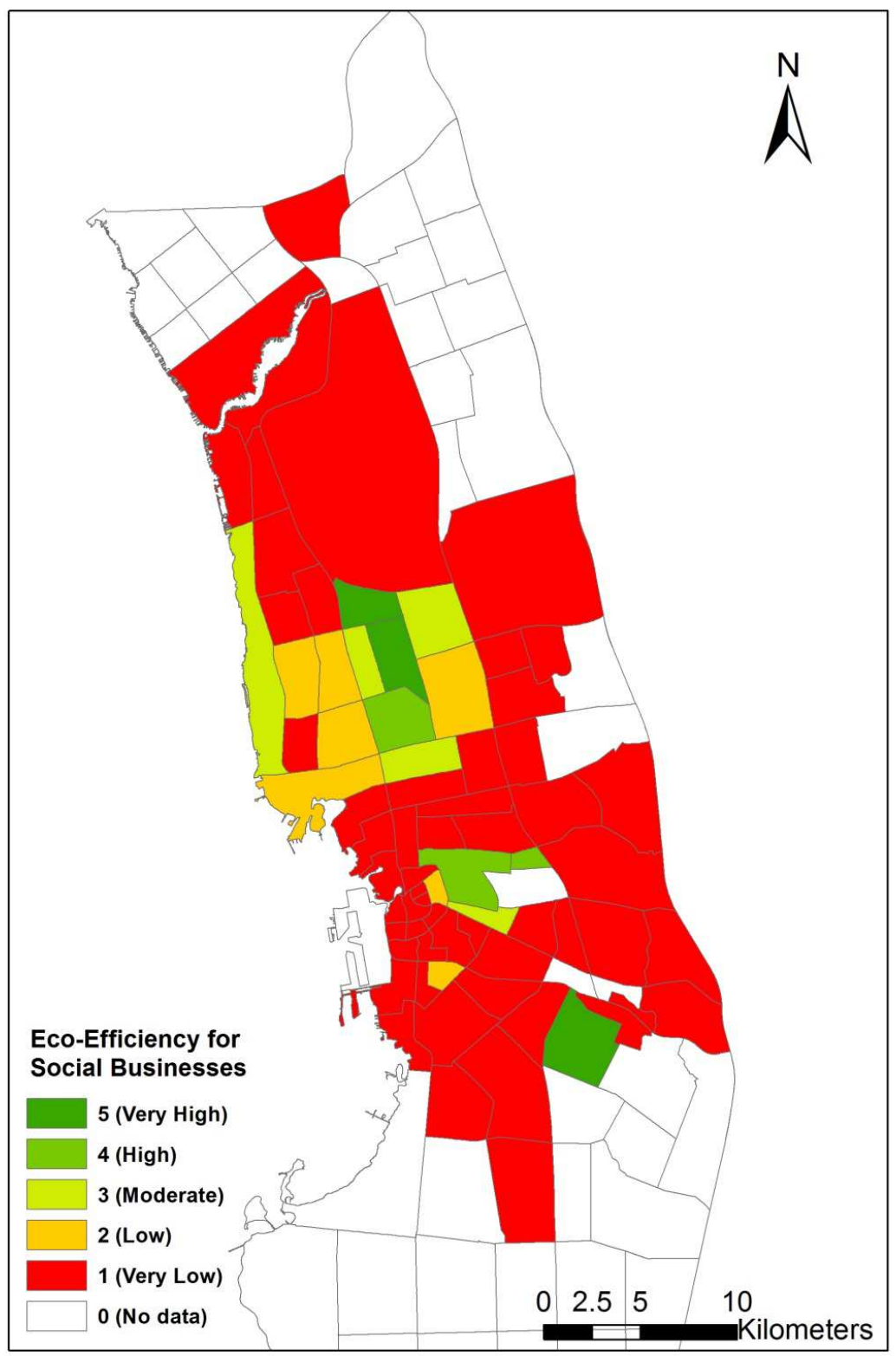

Fig. 7. Eco-efficiency for social businesses 
Mohammed Aljoufie and Alok Tiwari / American Journal of Environmental Sciences 2016, 12 (3): 152.168 DOI: 10.3844/ajessp.2016.152.168

\begin{tabular}{|c|c|c|c|c|c|}
\hline \multicolumn{2}{|c|}{$\begin{array}{l}\text { Table 12. District level eco-efficiency } \\
\text { generation in Jeddah }\end{array}$} & \multirow{2}{*}{$\begin{array}{l}\text { lid waste } \\
\% \\
\end{array}$} & \multicolumn{3}{|c|}{$\begin{array}{l}\text { Table 13. District level eco-efficiency of social businesses in } \\
\text { Jeddah }\end{array}$} \\
\hline $\mathrm{EE}_{\mathrm{sW}}$ & No. of districts & & $\mathrm{EE}_{\mathrm{sb}}$ & No. of districts & $\%$ \\
\hline Very low & 2 & 2.90 & Very low & 51 & 72.9 \\
\hline Low & 7 & 10.00 & Low & 8 & 11.4 \\
\hline Moderate & 21 & 30.00 & Moderate & 5 & 7.3 \\
\hline High & 20 & 28.55 & High & 3 & 4.2 \\
\hline Very high & 20 & 28.55 & Very high & 3 & 4.2 \\
\hline Total & 70 & 100.00 & Total & 70 & 100.0 \\
\hline
\end{tabular}

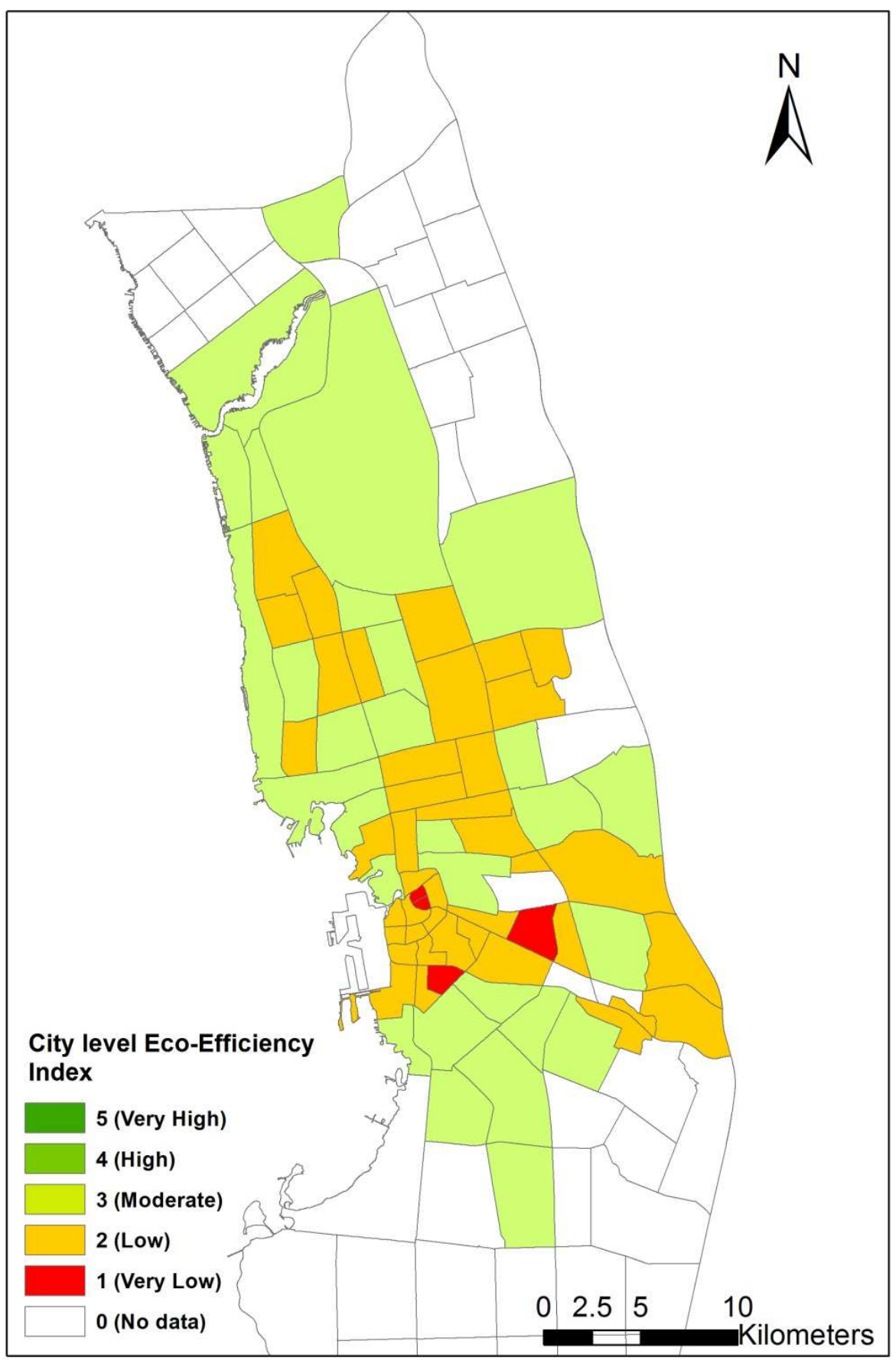

Fig. 8. City level eco-efficiency index 
Table 14. District level eco-efficiency of social businesses in Jeddah

\begin{tabular}{lcr}
\hline EE $_{\text {sb }}$ & No. of districts & $\%$ \\
\hline Very low & 4 & 5.41 \\
Low & 40 & 54.05 \\
Moderate & 30 & 40.54 \\
High & 0 & 0.00 \\
Very high & 0 & 0.00 \\
Total & 70 & 100.00 \\
\hline
\end{tabular}

Table 15. Relationship between population and urban infrastructure of Jeddah

\begin{tabular}{ll}
\hline Urban Infrastructure & Coefficient of correlation 'r' for population \\
\hline Public transportation infrastructure & 0.76 \\
Social business area & 0.05 \\
Energy (Electricity) consumption & 0.88 \\
Solid waste management infrastructure & 0.91 \\
Green infrastructure & 0.40 \\
Water supply & 0.85 \\
\hline
\end{tabular}

\section{Intra-City Eco-Efficiency Index}

Figure 8 and Table 14 depict the intra-city ecoefficiencies of urban infrastructure resources in the various districts of Jeddah.

Table 14 indicates that the eco-efficiency of $5.41 \%$ of the districts of Jeddah was very low, while the ecoefficiency of the urban infrastructure of $54.05 \%$ of the districts was found to be low, an issue of serious concern for decision makers and planners. The eco-efficiency level in the remaining $40.54 \%$ of the districts in Jeddah was determined to be moderate. No districts in Jeddah were found to be highly or very highly eco-efficient.

Areas deemed to be very low with respect to urban infrastructure eco-efficiency were distributed in a rather dispersed pattern in the city centre and drawn areas. Low-efficiency areas were distributed throughout the city in highly dense locales, while moderate eco-efficient areas were distributed in the urban peripheries that were comprised of new, low-density districts.

\section{Eco-Efficiency and Population Density}

Although this paper attempts to measure ecoefficiencies in spatial reference, it must also determine if there exists a relationship between eco-efficiencies and population. To determine the measured ' $r$ ' (correlation coefficient), population serves as the independent variable (x) and the infrastructure resources serve as the dependent variables. As shown in Table-15, a strong relationship was found between a district's population and available transportation routes $(r=0.76)$, energy consumption $(r=0.88)$, waste generation $(\mathrm{r}=0.91)$ and water consumption $(0.85)$. On the other hand, no association was found between population and social business areas (0.05) and a weak association $(\mathrm{r}=0.4)$ was found between population and green infrastructure availability.
A strong positive correlation between population and public transportation routes indicates that eco-efficiency increases as the population increases, while it decreases in terms of dense population in the case of energy use, water consumption and solid waste generation. No correlation between population and social business indicates that malls are not necessarily located in dense, deserted or newly expanded areas; hence, we cannot link a mall's eco-efficiency to population density. The weak association between population and green infrastructure reveals that eco-efficiency in reference to green infrastructure generally increases with the increase in population density, though there are exceptions.

\section{Eco-Efficiency Applicability for Urban Infrastructure in Jeddah}

Worldwide debates on sustainability indicate that eco-efficient, socially inclusive urban infrastructure is a perquisite for building competitive and liveable cities (UNESCAP, 2011). Eco-cities such as Dongtan (China) and Masdar (UAE) are the first two global cities that promise to offer excellent eco-efficiency by ensuring a zero carbon level (Premlatha et al., 2013). Though in a broad scenario, a closed materials cycle is likely difficult to enact in any city, this concept does not lead towards rejection but rather it encourages urban planners and decision makers to minimise resource waste, thereby lowering carbon emissions ( $\mathrm{Li}, 2014)$ and to maximise their economic and environmental values by innovative urban designs and ideas. In this respect, eco-efficiency is a pathway that leads towards integrated resource management. Thus, this paper adopts a simpler method to compute eco-efficiency and it offers an inspiration - as simpler is better; it proves also to be easier for the residents of Jeddah.

Major barriers in Jeddah from an eco-efficiency perspective include the following: 
Not only is there is a limited availability of public transportation routes, but public transportation is not perceived as a popular means of transportation among the city residents as it is not reliable and it is inadequate and uncomfortable. Nonetheless, it has been used widely by migrant workers because of it is a more affordable means of transportation. Thus, to address this problem, land uses in Jeddah should be well integrated with its transportation planning (Aljoufie, 2014). Further contributing to the problem is the fact that Jeddah is not a pedestrian friendly environment, a factor that negatively affects the city's liveability as walkability in a city not only improves its eco-efficiency, but it apparently also improves urban health and liveability (Shamsuddina et al., 2012; Bhattacharyyaa and Mitra, 2013; Ariffin and Zahari, 2013). Walkability in a city supports a mass rapid public transportation system, which cumulatively contributes to a decrease in the carbon footprint and increase in eco-efficiency. The same is true for bicycle riding. Given the benefits of enhancing a city's walkability, Jeddah's strategic plan should include Transit Oriented Development (TOD) as it may contribute to achieving public transport linked eco-efficiency (Wey and Chiu, 2013). However, this must be supported by an efficient public transportation system in conjunction with restrictions on private vehicle use.

As water and energy in the city of Jeddah are acquired by hydrocarbons, their linear consumption can have a greater negative impact on the environment, which means a notable decrease in eco-efficiency. The arid climate of the city creates a greater demand on energy for air-conditioning, while increased water consumption produces a series of consequences including the generation of greater amounts of wastewater, which must be treated, thus using more energy. Hence, energy intensive (a special reference to fossil fuel) approaches to the provision and extension of the infrastructure is not sustainable. Accordingly, a holistic water and energy management approach is critical for Jeddah, A higher environmental cost is involved in seawater desalination which can be minimised by maximising renewable energy uses leading into improved eco-efficiency performance of both Water and Energy Infrastructure resources (Purnamaa et al., 2005; García-Rodríguez, 2002).

The increased amount of solid waste generated in some districts is a critical factor that hampers environmental sustainability to a large extent as resource recovery, recycling, reducing and reusing is not often practiced in the city. Thus, separation (Mbiba, 2014) of solid waste at the source is vital as it results in $3 R$ (reduce, reuse and recycle) actions.

Though social business areas in the city are adequately provisioned, there are variations at the district level and many districts still require more social spaces to enhance their eco-efficiency. Thus, an efficient urban centre hierarchy system that promotes social justice is highly recommended.

Finally, eco-efficiency of green infrastructure is significant as Jeddah does not have an adequate amount, partly due to the challenges presented by the arid climate. The expansion of green spaces improves the eco-efficiencies of many infrastructure resources as it consumes organic waste after the recycling of solid waste and it contributes substantially to the cooling of the city, which leads to energy savings and promotes walkability in the city by providing shade and protection from the sun and arid weather while absorbing carbon emission from automobiles. Accordingly, the expansion of green infrastructure in Jeddah, implemented on a priority basis, offers multiple advantages.

Improvements in infrastructure resource efficiency are often considered the first step towards sustainable resource management (Hawken et al., 2010; Von Weizsäcker et al., 2009; Natalia and Kennedy, 2008). Adopting technological innovations, strengthening local institutions (Chan et al., 2013) and enhancing the efficient capacity building are important strategies as Jeddah transitions towards eco-efficiency and low-carbon emission. As eco-efficiency in Jeddah cannot be planned and achieved in isolation, there is an urgent need to prepare an integrated strategic plan for the city to tackle the sustainability challenges that the city's infrastructure is currently facing.

\section{Conclusion}

Urban infrastructures in Jeddah are in a transitional phase as they continue to experience rapid growth. At this juncture, measuring the sustainability of these infrastructures with the help of eco-efficiency indicators has greater importance because eco-efficiency is vital for integrated and sustainable infrastructure resource management.

Eco-efficiency indicators at the city level were developed to measure the intra-city spatial eco-efficiency of selected urban infrastructure amenities in the city of Jeddah. Results indicate that low eco-efficiency dominates Jeddah's urban infrastructure and that there is an emerging need for an integrated strategic plan for the city to tackle sustainability challenges with respect to urban infrastructure, it paves the framework for the retrofitting, replacing and expansion of infrastructure whatever and wherever required.

Eco-efficiency paves the way for decoupling economic benefits from environmental improvements, which is a perquisite to establishing a liveable and competitive city. Eco-efficiency intimates a notion for 
urban planners, designers and policymakers to work together for the city's branding as a green place. Furthermore, it calls for more in-depth investigations regarding resource efficiency deficits.

\section{Acknowledgment}

We would like to acknowledge our gratitude to the Faculty of Environmental Design, King Abdul Aziz University, Jeddah, Kingdom of Saudi Arabia for offering logistics.

\section{Author's Contributions}

This work is an consequence of the complete cooperation of both authors.

Mohammed Aljoufie: Contributed in the planning of study, data collection, data exploration and presentation of GIS based thematic mapping. He wrote and reviewed the manuscript.

Alok Tiwari: Participated in the preparation and design of the study; data processing and analysis. He paid his efforts in the writing and the revision of the manuscript.

\section{Ethics}

The authors declare that this is an original research and do not have any ethical issues or copyrights conflict.

\section{References}

AECOM, 2012. Jeddah spatial framework plan in association with the Jeddah stormwater drainage program JSDP WER-008 Emirate of Makkah.

Alberti, M., J.M. Marzluff, E. Shulenberger, G. Bradley and C. Ryan et al., 2003. Integrating humans into ecology: Opportunities and challenges for studying urban ecosystems. Bioscience, 53: 1169-1179. DOI: 10.1641/0006-3568(2003)053[1169

Aljoufie, M., M. Zuidgeest, M. Brussel and M.V. Maarseveen, 2013. Spatial-temporal analysis of urban growth and transportation in Jeddah City, Saudi Arabia. Cities, 31: 57-68.

DOI: $10.1016 /$ j.cities 2012.04 .008

Aljoufie, M., 2014. Toward integrated land use and transport planning in fast-growing cities: The case of Jeddah, Saudi Arabia. Habitat Int., 41: 205-215. DOI: 10.1016/j.habitatint.2013.08.010

Al-Sefry, A.S. and Z. Şen, 2006. Groundwater rise problem and risk evaluation in major cities of arid lands-Jedddah Case in Kingdom of Saudi Arabia. Water Resources Manage., 20: 91-108. DOI: $10.1007 / \mathrm{s} 11269-006-4636-2$
Ariffin, R.N.R. and R.K. Zahari, 2013. Perceptions of the urban walking environments. Proc. Soc. Behav. Sci., 105: 589-597.

DOI: $10.1016 /$ j.sbspro.2013.11.062

Beck, M.B. and R.G. Cummings, 1996. Wastewater infrastructure: Challenges for the sustainable city in the new millennium. Habitat Int., 20: 405-420. DOI: 10.1016/0197-3975(96)00022-7

Bhattacharyyaa, D.B. and S. Mitra, 2013. Making Siliguri a Walkable City. Proc. Soc. Behav. Sci., 96: 2737-274. DOI: 10.1016/j.sbspro.2013.08.307

Bulkeley, H., V.C. Broto, A. Maassen, H. Bulkeley and V.C. Broto et al., 2014. Low-carbon transitions and the reconfiguration of urban infrastructure. Urban Stud., 51: 1471-1486. DOI: $10.1177 / 0042098013500089$

Byström, J., 2012. Eco efficiency, a path towards integrated resource management. Waste Manage., 32: 797-798. DOI: 10.1016/j.wasman.2012.01.022

Chan, E.H.W., L.H.T. Choy and E.H.K. Yung, 2013. Current research on low-carbon cities and institutional responses. Habitat Int., 37: 1-3. DOI: 10.1016/j.habitatint.2011.12.007

Choguill, C.L., 1996. Ten steps to sustainable infrastructure. Habitat Int., 20: 389-404.

DOI: $10.1016 / 0197-3975(96) 00013-6$

Huang, C.L., J. Vause, H.W. Ma and C.P. Yu, 2013. Urban water metabolism efficiency assessment: Integrated analysis of available and virtual water. Sci. Total Environ., 452-453: 19-27. DOI: 10.1016/j.scitotenv.2013.02.044

Da Silva, C.E., A.E. Hoppe, M.M. Ravanello and N. Mello, 2005. Medical wastes management in the south of Brazil. Waste Manage., 25: 600-605. DOI: 10.1016/j.wasman.2004.03.002

Diaz, L.F., G.M. Savage and L.L. Eggerth, 2005. Alternatives for the treatment and disposal of healthcare wastes in developing countries. Waste Manage., 25: 626-637.

DOI: 10.1016/j.wasman.2005.01.005

Fet, A.M., 2003. Eco-efficiency reporting exemplified by case studies. Clean Tech. Environ. Policy, 5: 232-239. DOI: $10.1007 / \mathrm{s} 10098-003-0205-\mathrm{z}$

Freeman, M.A., K. Haveman and A.V. Kneese, 1973. The Economics of Environmental Policy. 1st Edn., John Wiley and Sons, Malabar, ISBN-10: 0898747414, pp: 184.

Grimm, N.B., S.H. Faeth, N.E. Golubiewski, C.L. Redman and J.G. Wu et al., 2008. Global change and the ecology of cities. Science, 319: 756-60.

DOI: $10.1126 /$ science. 1150195

Hawken, P., A.B. Lovins and L.H. Lovins, 2010. Natural Capitalism: The Next Industrial Revolution. 1st Edn., Routledge, ISBN-10: 1134033060, pp: 448. 
JM, 2009. Jeddah Strategic Plan. Jeddah Municipality.

Kambites, C. and S. Owen, 2006. Renewed prospects for green infrastructure planning in the UK. Plann. Pract. Res., 21: 483-496.

DOI: $10.1080 / 02697450601173413$

Krellenberg, K., J. Welz and S. Reyes-Päcke, 2014. Urban green areas and their potential for social interaction-a case study of a socio-economically mixed neighbourhood in Santiago de Chile. Habitat Int., 44: 11-21.

DOI: $10.1016 /$ j.habitatint.2014.04.004

Kuosmanen, T., 2005. Measurement and analysis of ecoefficiency-an economist's perspective. J. Industr. Ecol., 6: 15-18.

Li, Y., 2014. Low carbon eco-city: New approach for Chinese urbanisation. Habitat Int., 44: 102-110. DOI: 10.1016/j.habitatint.2014.05.004

Mbiba, B., 2014. Urban solid waste characteristics and household appetite for separation at source in Eastern and Southern Africa. Habitat Int., 43: 152-162. DOI: 10.1016/j.habitatint.2014.02.001

Mickwitz, P., M. Melanen, U. Rosenstrom and J. Seppala, 2006. Regional eco-efficiency indicators-a participatory approach. J. Cleaner Prod., 14: 1603-1611. DOI: 10.1016/j.jclepro.2005.05.025

Mitlin, D. and S. Satterthwaite, 1996. Sustainable Development and Cities. In: Sustainability, the Environment and Urbanisation, Pugh, C. (Ed.), Earthscan, London.

Natalia, C. and C.A. Kennedy, 2008. Metabolism of neighborhoods. J. Urban Plann. Dev., 134: 21-31. DOI: 10.1061/(ASCE)0733-9488(2008)134:1(21)

Premlatha, M., S.M. Tauseef, T. Abbasi and S.A. Abbasi, 2013. The promise and the performance of the world's first two zero carbon eco-cities. Renewable Sustainable Energy Rev., 25: 660-669. DOI: 10.1016/j.rser.2013.05.011

Purnamaa, A., H.H. Barwania and R. Smith, 2005. Calculating the environmental cost of seawater desalination in the Arabian marginal seas. Desalination, 185: 79-86.

DOI: $10.1016 /$ j.desal.2005.03.072

Ribarova, I., P. Stanchev, G. Dimova and A. Assimacopoulos, 2013. First iteration of an ecoefficiency assessment of Sofia's urban water system. Proceedings of the 12th International Conference on Computing and Control for the Water Industry, (CWI' 2013).

Richard, A.F., B. Sheffler, J. Meoli and A. Rummel, 1989. There's something social happening at the mall. J. Bus. Psychol., 4: 49-63.

DOI: $10.1007 / \mathrm{BF} 01023038$

García-Rodríguez, L., 2002. Seawater desalination driven by renewable energies: A review. Desalination, 143: 103-1 13. DOI: $10.1016 / \mathrm{S} 0011-9164(02) 00232-1$
Rotich, K.H., Z. Yonsheng and D. Jun, 2006. Municipal solid waste management challenges in developing countries- Kenyan case study. Waste Manage., 26: 92-100. DOI: 10.1016/j.wasman.2005.03.007

Rouse, J.R., 2006. Seeking common ground for people: Livelihoods, governance and waste. Habitat Int., 30: 741-753.

DOI: $10.1016 /$ j.habitatint.2005.09.001

Schaffer, D. and D. Vollmer, 2010. Pathways to Urban Sustainability: Research and Development on Urban Systems. 1st Edn., The National Academies Press, Washington, DC.

Schäffler, A. and M. Swilling, 2013. Valuing green infrastructure in an urban environment under pressure-the Johannesburg case. Ecol. Econom., 86: $246-257$.

DOI: 10.1016/j.ecolecon.2012.05.008

Schaltegger, S. and A. Sturm, 1990. Ökologische rationalität. Die Unternehmung, 4: 273-290.

Shamsuddina, S., N.R.A. Hussan and S.F.I. Bilyamin, 2012. Walkable environment in increasing the Liveability of a City. Proc. Soc. Behav. Sci., 50: 167-178. DOI: 10.1016/j.sbspro.2012.08.025

Singh, R.K., H.R. Murthy, S.K. Gupta and A.K. Dikshit, 2009. An overview of sustainability assessment methodologies. Ecol. Indicators, 9: 189-2012.

DOI: 10.1016/j.ecolind.2008.05.011

Suocheng, D., K.W. Tong and Y. Yuping, 2001. Municipal solid waste management in China: Using commercial management to solve a growing problem. Utilities Policy, 10: 7-11. DOI: 10.1016/S0957-1787(02)00011-5

UN, 2009. Eco-efficiency indicators: Measuring resource use efficiency and the impact of economic activities on the environment. Publication Team, Ichimura, M., S. Nam, S. Bonjour, H. Rankine and B. Carisma, Rep. United Nations Economic and Social Commission for Asia and the Pacific.

UNDP, 2012. Green economy in action. Articles and Excerpts that Illustrate Green Economy and Sustainable Development Efforts.

UNESCAP, 2011. Are we building competitive and liveable cities? Guidelines for developing ecoefficient and socially inclusive infrastructure. UN Publications, Bangkok.

UN-HABITAT, 2012a. The State of Arab Cities 2012 Challenges of Urban Transition. United Nations Human Settlements Programme, UN-Habitat, Nairobi.

UN-HABITAT, 2012b. State of the World's Cities Report 2012/2013: Prosperity of Cities, Nairobi. 
Von Weizsäcker, E., K. Hargroves, M. Smith, C. Desha and P. Stasinopoulos, 2009. Factor five: Transforming the global economy through $80 \%$ improvements in resource productivity. Earthscan, London.

Wey, W.M. and Y.H. Chiu, 2013. Assessing the walkability of pedestrian environment under the transit-oriented development. Habitat Int., 38: 106-118. DOI: 10.1016/j.habitatint.2012.05.004

WBCSD, 2000. Eco-efficiency: Creating More Value with Less Impact (North Yorkshire 2000). World Business Council for Sustainable Development.
WCED, 1987. Our common future. World Commission on Environment and Development, Oxford University Press, Oxford.

Zhang, B. G.D. Xie, J.X. Gao and Y. Yang, 2014. The cooling effect of urban green spaces as a contribution to energy-saving and emissionreduction: A case study in Beijing, China. Build. Environ., 76: 37-43.

DOI: $10.1016 /$ j.buildenv.2014.03.003 